\title{
„КУЋА МУДРОСТИ“ И АРАПСКЕ ПРЕВОДИЛАЧКЕ АКТИВНОСТИ У СРЕДЊЕМ ВЕКУ
}

\section{Сажетак}

Кућа мудрости“, ар. Bayt al-hikma, за коју се често каже да ју је у Багдаду основао син чувеног Харуна ел Рашида, халифа Мамун (al-Ma'mūn) 830. године, у историографској литератури и изворима најчешће се помиње као преводилачки центар, библиотека и академија, централно место арапског преводилачког „покрета“ у средњем веку. У релевантној литератури која разматра тај историјски период и преводилачке активости, постоји неслагање око стварне природе и улоге ове институције у интензивним и обимним арапским средњовековним преводилачким активностима филозофских, научних, медицинских, књижевних и других дела писаних на грчком, персијском, санскриту, арамејском итд.

Већина секундарне историографске литературе заиста описује „Кућу мудрости“ као грандиозну преводилачку институцију са извесним модерним организационим елементима, при чему се посебно истиче координација рада шездесет пет преводилаца за грчки, сиријачки, персијски, арамејски и санскрит. Новије студије пак тврде да за већину тих тврдњи нема поузданих доказа: нити да је „Кућу мудрости“ основао халифа Мамун или његов отац Харун ел Рашид, ни да су се ту обављали преводи са било ког другог језика осим са персијског. Према тим изворима, „Кућа мудрости“ највероватније јесте била библиотека, део абасидске администрације са примарном функцијом инстутитуционализације превођења са персијског и очувања тако стечених резултата. У овом раду се критички анализирају различита виђења те значајне институције и њене улоге у арапским преводилачким активностима, као и разлози за тако опречна гледишта.

Кључне речи: Кућа мудрости, Bayt al-ḥikma, историја превођења, арапске преводилачке активности

Филолошки факултет, Студентски трг 3, 11000 Београд

dragana.djordjevic@fil.bg.ac.rs 


\section{1. Увод}

У релевантној литератури која разматра арапски средњи век и тадашње интензивне преводилачке активости постоји неслагање око стварне природе и улоге коју је у тим активностима имала Кућа мудрости, ap. Bayt al-hikma, државна институција која је основана средином прве половине 9. века у Багдаду.

У овом раду смо критички анализирали различита виђења ове абасидске државне институције и њене улоге у интензивним и обимним арапским средњовековним преводилачким активностима филозофских, научних, медицинских, књижевних и других дела писаних на грчком, персијском, санскриту, арамејском и другим језицима, као и могуће разлоге за тако опречна гледишта. При томе смо се користили најрелевантнијом доступном примарном и секундарном литературом, а најпре: Baker, M. (ed.) (2005). Routledge Encyclopedia of Translation Studies. London: Routledge; Gutas, D. (1998). Greek Thought, Arabic Culture: the Graeco-Arabic translation movement in Baghdad and early 'Abbasid society (2nd-4th/8th-10th centuries). London: Routledge; 'Itmān, 'A. (2013). al-Munğaz al-'arabī al-'islāmī fi al-tarğama wa hịārr al-țaqāfāt min Baġdād 'ilā Țulayțila. Al-Qāhira: al-Hay'a al-mișriyya al'āmma li al-kitāb; Meri, J. W. (ed). (2006). Medieval Islamic civilization: an encyclopedia. New York: Routledge.

\section{2. Кућа мудрости у секундарној историјској и транслатолошкој литератури}

Већина секундарне историографске литературе описује Кућу мудрости као грандиозну преводилачку институцију са извесним модерним организационим елементима, при чему се често посебно истиче координација рада шездесет пет преводилаца за грчки, сиријачки, персијски, арамејски и санскрит. Одличан пример таквог описа налазимо у поглављу које се бави историјатом превођења код Арапа у Рутличовој Енциклопедији транслатолошких проучавања (Routledge Encyclopedia of Translation Studies): 
„The second Abbasid caliph al-Manșūr (reined 754-75), comissioned a number of translations and set up a translation chamber. Al-Rashīd (reined 786-809) similarly supported translation activity and enlarged the translation chamber set up by al-Manșūr. But it was al-Ma'mūn who founded in 830 the most important institute of higher learning in Islam, which also became the most celebrated centre of translation in Arab history. Bayt al-Hikma (House of Wisdom), in Baghdad, functioned as an academy, library and translation bureau and had personnel of 65 translators, working from Greek, Syriac, Persian, Sanskrit and Aramaic"1 (Baker 2005: 319-320).

За ово наше истраживање важна је још једна тврдња изнета у овој значајној транслатолошкој енциклопедији, а то је да је Хунеин ибн Исхак (Hunayn ibn 'Ishāq), у Европи познат под својим латинизованим именом Јоанитијус (Joannitius), вероватно најпознатији преводилац те епохе, био управник Куће мудрости (Baker 2005: 324-325).

Описе Куће мудрости сличне претходно наведеном налазимо и у бројној другој релевантној секундарној литератури (Т̦āha 1976: 347-358; Versteegh 2006: I, 403; Osman 2011: 113-114). ${ }^{2}$ Међутим, како смо у уводу овог рада то већ нагласили, у литератури, чак и оној на коју смо до сада упутили, постоје прилична неслагања око бројних појединости, на пример, године оснивања ове институције, њеног оснивача, као и саме њене природе.

Када је реч о тачној години оснивања ове институције, а уједно и њеном оснивачу, наилазимо на опречне податке. У Хитијевој

1 „Други абасидски халифа Мансур (владао од 754. до 775.) наручио је известан број превода и успоставио преводилачку канцеларију. Рашид (владао од 786. до 809.) је на сличан начин подржавао преводилачке активности и приширио преводилачку канцеларију коју је Мансур основао. Ипак, Мамун је био тај који је 830. основао најважнију институцију вишег образовања у исламу, а која је уједно постала најчувенији преводилачки центар у арапској историји. Bayt al-Hikma (Кућа мудрости), у Багдаду, функционисала је као библиотека и преводилачка канцеларија, а њено особље је чинило шездесет пет преводилаца који су радили са грчког, сиријачког, персијског, санскрита и арамејског."

2 С друге стране, интересантно је да се у иначе темељној Хуранијевој Историји арапских народа Кућа мудрости уопште не помиње ни у каквом контексту, иако се разматрају арапске преводилачке активности у средњем веку. Видети у Хурани, А. Историја арапских народа. Београд: Клио, 2016, 118-120. 
Историји Арапа налазимо податак да је ова установа основана 830. године и да је њен оснивач халифа Мамун (Hiti 1988: 287), а на овај извор се позива и Рутличовој Енциклопедији транслатолошких проучавања (Baker 2005: 320). У Енциклопедији ислама и исламског света стоји пак податак да ју је 832. године у Багдаду основао халифа Мансур (Martin 2004: 282), али ту тврдњу морамо одбацити, јер је Мансур владао од 754. до 775. године. Године 832. могао ју је основати само Мамун. С друге стране, Сурдел у Енциклопедији ислама указује на то да је врло могуће да је ова институција, под нешто другачијим именом (hizānat al-ḥikma - „ризница или библиотека мудрости“) постојала још у доба чувеног халифе Харуна Рашида, а да је његов син Мамун тој институцији заправо дао „нови подстицај“ за рад. У вези са тачном годином оснивања Сурдел остаје опрезан и не прецизира је, али зато тврди да је ова институција без сумње имитација древне академије у Гундишапуру, као и да је главна активност Куће мудрости било превођење са грчких изворника које су у абасидско царство из Византије доносиле званичне државне делегације, као и астрономска проучавања (Sourdel 1986 : I, 1141).

Сурдел, дакле, такође тврди да се у Кући мудрости преводило само са грчког, иако је модел институције био сасанидски, за разлику од претходно наведеног тумачења које нам нуди Рутлицовој Енциклопедији транслатолошких проучавања, да је ту превођено са грчког, персијског, сиријачког, арамејског и санскрита (Sourdel 1986 : I, 1141; Baker 2005: 320). Извори се, и то не само ова два, не слажу ни око језика са којих је превођено.

Критички поглед на различите податке и интерпретације настанка, природе и историјата ове функције даје једна новија студија, Greek Thought, Arabic Culture: the Graeco-Arabic translation movement in Baghdad and early 'Abbasid society (2nd-4th/8th-10th centuries) из 1999. године. Аутор ове студије, Димитри Гутас, као светски стручњак за историју превођења античког грчког наслеђа на арапски језик тврди пак да за већину претходно наведених тврдњи нема поузданих доказа: нити да је Кућу мудрости основао халифа Мамун или пак његов отац Харун Рашид, ни да су се 
ту обављали преводи са било ког другог језика осим са персијског. Он истиче да је Кућа мудрости највероватније јесте била библиотека, део абасидске администрације створен по сасанидском моделу са примарном функцијом инстутитуционализације превођења са персијског и очувања тако стечених резултата. Такве тврдње заснива на основу непосредног увида у примарне историографске изворе. Према Гутасу, ова институција није имала образовни карактер, нити било какве везе са активностима превођења са грчког на арапски, али јесте створила погодну климу за успешан развитак тзв. грчко-арапског преводилачког покрета (Gutas, 1999: 55-59).

Што се енциклопедија тиче, Енциклопедија средњовековне исламске цивилизације (Medieval Islamic civilization: an encyclopedia) издавачке куће Рутлиџ даје можда и најобјективнији преглед расположивих фактографских података о Кући мудрости што се западне арабистичке литературе тиче, уз недвосмислено прихаватање Гутасовог мишљења о тој теми као најутемељенијег. Жилијо закључује да је велика вероватноћа да је Кућа мудрости основана још за време Мансурове владавине, а да је своје златне дане доживела за време Мамуна, или већ Мамуновог оца, Харуна Рашида, као и да је с временом мењала функције које је вршила. Такође се инсистира да су се ту вршили преводи само са персијског (Gilliot, 2006: 450-451). ${ }^{3}$

Вреди поменути мишљење још једног великог стручњака за историју преводилаштва код Арапа у средњем веку, египатског класичног филолога Ахмеда Итмана који је то питање подробно размотрио у својој студији al-Munğaz al-'arabì al-'islāmī fī al-tarğama wa ḥiwār al-țaqāfāt min Baġdād 'ilā Tulayțila - „Арапско-исламски допринос превођењу и дијалогу култура од Багдада до Толеда“ из 2013. године, која уједно представља најновију и најтемељнију студију која се бави том темом. Већ на почетку поглавља у којем

Реч је, иначе, о делу изузетно информативног и корисног чланка о библиотекама на арапско-исламској територији у средњем веку који свеукупно нуди врло драгоцене и објективне податке о најважнијим библиотекама у том периоду које су биле разасуте од Багдада, преко Каира, па све до арапске Шпаније. У вези са тим, видети Gilliot, C. „Libraries". У: Medieval Islamic civilization: an encyclopedia; Meri, J. W. (ed). New York: Routledge, 2006, 450-454. 
се бави Кућом мудрости, Итман констатује да се много тога у вези са овом институцијом претворило малтене у легенду, а најпре да ли је уопште постојала, ко је њен оснивач и која је била њена функција. Он наводи да доста извора приписује оснивање Куће мудрости Харуну Рашиду, по чијој наредби је ту донето много књига са освојених византијских територија и који је управљање поверио великом средњовековном преводиоцу, Ибн Масавејху, а да је институција свој врхунац доживела за време Мамуна, који је пак управу поверио Сехлу ибн Харуну. Наводи и да су књиге имале тематску класификацију и да су бирани преводиоци који ће на њима радити, а да се преводило са грчког, сиријачког, персијског, санскрита и коптског ('Itmān 2013: 127-128). Чак указује на то да је Ибн Недим (10. век) сматрао да је разлог за тако интензивно интересовање за грчка филозофска дела последица тога што се Мамуну јавио Аристотел у сну, иако да то никако није био почетак интензивних преводилачких активности, јер се почетак везује за халифу Мансура, чиме оповргава раније наведено тумачење Ибн Усајбије (13. век), да је Мамун оснивач Куће мудрости ('Itmān 2013: 128-129). Итман, који је у овој студији користио импозантну литературу, критикује Гутасов став да је Кућа мудрости установљена по персијском, то јест сасанидском моделу, а који је заснован на мишљењу персијског историчара Хамзе Исфаханија (9-10. век). Иако констатује да чак ни стари арапски извори не нуде довољно информација о Кући мудрости, Итман сматра да није тачно да је прављена по персијском моделу, већ да су мислимани, а особито Мамун, преузели александријски модел: „Wa kānat maktabat al'Iskandariyya wa 'ulūm al-'Iskandariyya hiya allatī yaḥlumu bimițlihā alhulafā' wa fĩ muqaddimatihim al-Ma'mūn"4 ('Itmān 2013: 130). Kao n у Рутличовој енциклопедији транслатолошких истраживања, и Итман тврди да је Хунеин ибн Исхак био управник Куће мудрости, али нешто касније, за време владавине халифе Мутевекила који је владао од 847. до 861. године ('Itmān 2013: 131). 
Наравно, ми никако нисмо исцрпели листу свих неслагања и различитих мишљења и интерпретација у секундарним изворима, али верујемо да представљени налази дају добру илустрацију разноликости расположивих података.

Оно што читаву тему чини још занимљивијом јесте да се наведена истраживања, непосредно или посредно, већински темеље на готово идентичним арапским примарним изворима, а најпре на списима Ибн Недима, Ибн Усајбије и посредно Ибн Џулџула, које ћемо, између осталог, разматрати у наредном делу рада, уз Посланицу Алију ибн Јахји о преведеним Галеновим књигама и неким које још нису преведене Хунеина ибн Исхака.

\section{3. Кућа мудрости у примарној историјској литератури}

Прво ћемо се бавити Каталогом Ибн Недима (умро 995. године). Дело Kamaлог, ар. Fihrist, завршено је 987. или 988. године и представља опсежан индекс свих књига написаних на арапском до тог времена, било да су их писали Арапи или Неарапи. Знатна пажња је посвећена управо преводима филозофских и научних дела са грчког, као и дела која су на основу тих превода настала (Fück 1986: III, 895). Ибн Недим се у више наврата у том делу осврнуо на превођење и на Кућу мудрости. За нас су посебно значајна следећа поглавља: а) Поглавље Навођење разлога због ког има много филозофских и других књига (ар. Dakr al-sabab alladī min 'ağlihi katurat kutub al-falsafa wa ġayruhā), у којем представља приповест о томе како је Мамун сањао Аристотела, што је подстакло његово интересовање за филозофију, па је после чак писао византијском цару и замолио га да му да̂ старогрчка дела, што је тај владар наводно одбио, да би Мамун на крају ипак успео да набави бројне књиге из филозофије, музике, геометрије, аритметике, медицине и музике. Наводи да је у томе учествовало много преводилаца, нпр. Масавејхи, којег други извори помињу као управника Куће мудрости и извесног Селму, управника Куће мудрости, очито за време Мамуна (Ibn al-Nadīm 1964: 339-340); Поглавље Имена преводилаца 
са различитих језика на арапски (ар. 'Asmā' al-naqala min al-luġāt 'ilā al-lisān al-'arabī) и поглавље Имена преводилаца са персијског на арапски (ар. 'Asmā' al-naqala min al-fārisī 'ilā al-'arabī) у којима даје имена преводилаца, неке биографске податке, као и дела која су превели (Ibn al-Nadìm 1964: 340-342); в) поглавље Имена познавалаца реторике (ар. 'Asmā' al-bulag் $\bar{a}$ ') у којем ниже мноштво имена писаца и преводилаца који су, према његовом мишљењу, добро владали реториком, а између осталог и једног управника Куће мудрости (ap. șāḥib Bayt al-ḥikma), Сехла ибн Харуна који је умро 830. године, дакле оне године када је наводно основана ова институција (Ibn al-Nadīm 1964: 181-182). Из текста је јасно да Ибн Недим није покушавао да успостави јаснију хронологију, нити је понудио више детаља у вези са радом те институције.

Ибн аби Усајбиа (1194-1270) је био лекар и библиограф који је живео у Дамаску. Његово једино преостало дело које је уједно за нас овде значајно јесте Преглед историје лекара, ар. 'Uуйn al'anbā' fi țabaqāt al-'ațibbā' из 13. века, где наводи биографије научника који су дали допринос за развој природних наука код Арапа. За нас је значајна примедба коју о њему износи Верне у Енциклопедији ислама, а то је да је код Ибн аби Усајбије уочљиво да је доста преписивао од својих претходника, већ помињаног Ибн Џулџула (Vernet 1986: III, 693-694). Ибн Џулџул (944-994) јесте лекар из арапске Шпаније, значајанзбог своје Историје лекара, ap. Tārīh al-'ațibbā' као најстарије збирке биографија арапских лекара (Dietrich 1986: III, 755-756), а која нам нажалост није била доступна. У поглављу посвећеном Хунеину ибн Исхаку, који је чувен и као преводилац, али и као надарени офталмолог, Ибн Усајбиа одиста наводи причу о томе како се Мамуну у сну јавио Аристотел, те да се због тог сна заинтересовао за његово филозофско дело и позвао Хунеина ибн Исхака да му он објасни о коме је реч (Ibn 'Ușaybi'a s.a.: 259). Ако прихватимо Вернеов став да је Ибн Усајбиа преписивао од Ибн Џулџула, а потом у обзир узмемо да је навео упрошћену и мало „дотерану“ верзију приче коју је навео Ибн Недим, а која је хронолошки прва настала, немогуће је отети се утиску да је прво Ибн Џулџул 
„позајмио“ ту причу од Ибн Недима, па онда Ибн Усајбиа од Ибн Џулџула.

Што се тиче тврдњи које налазимо код Ибн Усајбије и касније у Рутличовој енциклопедији транслатолошких проучавања у вези са тим да је Хунеин ибн Исхак (806-873 ili 877) био управник Куће мудрости, та њу нисмо могли да нађемо никакву потврду у Ибн Исхаковој Посланици Алију ибн Јахји о преведеним Галеновим књигама и неким које још нису преведене (ap. Risalat Hunayn ibn Isḥāq 'ilā 'Alī ibn Yahyyā fi dikr mā turğima min kutub Ğalīnūs bi 'ilmihi wa ba'ḍ mā lam yutarğam), у коју смо имали увид на основу најновијег критичког издања тог текста: Lamoreuax, J. C. (editor \& translator). Hunayn Ibn Ishāa on His Galen Translations. Provo: Brigham Young University Press, 2016. Ибн Исхаку се приписује огроман број преведених наслова, махом из области медицине којом се и са̂м бавио. Стога је и понео надимак „шејх преводилаца“ (Morrison 2006: 336-337). У својој Посланици Алију ибн Јахји о преведеним Галеновим књигама и неким које још нису преведене дао је опсежну библиографију преведених Галенових дела, као што је наводио ко је који превод наручи. ${ }^{5}$ Индикативно је да ниједном речју није поменуо икакву везу са Кућом мудрости нити са абасидском владајућом гарнитуром, а из текста се јасно види да је Ибн Исхак био свестан својих квалитета и волео да истиче своје подухвате. Ипак, пошто је ова посланица настала око 856. године, не можемо сасвим искључити да је можда касније био на том положају.

\section{4. Закључак}

Иако нисмо ни издалека успели да представимо сва постојећа виђења Куће мудрости, њеног историјата и улоге у арапским преводилачким активностима у средњем веку, истраживањем смо обухватили најрелевантнију примарну и секундарну литературу која

5 Дотакао се и питања као што су преводилачке компетенције, дослован и слободан превод, публика којој је превод намењен, поновно превођење, при чему је нудио увид у своја практична преводилачка искуства. 
представља неизоставне референце за сваког ко је намеран да се дотакне теме арапских преводилачких активности у средњем веку.

С обзиром на то да се проучена литература непосредно или посредно заснива на истим изворима, а опет нуди више опречности од слагања, како у погледу године оснивања и оснивача, тако и у погледу функције и организације Куће мудрости, главни закључак који се намеће јесте да арапске преводилачке активности у средњем веку, а самим тим и Кућа мудрости која се неретко узима као њен главни покретач и симбол, нису адекватно проучене.

За већи део примарне, али и секундарне литературе, практично без разлике, важи исто, а то је некритичко разматрање примарних извора и неретко произвољно тумачење информација које се тамо налазе. Сматрамо да је то посебно проблематично у секундарној литератури новијег датума, насталој у 20. и 21. веку, дакле у периоду када је већ постоји јасна методологија критичког научног истраживања. На пример, ниједан од аутора који су истраживања непосредно заснивали на средњовековним изворима, а најпре на Ибн Недиму и његовом Каталогу као најважнијем, не узима у обзир веома важну чињеницу да Ибн Недим није био савременик Куће мудрости, већ је давао накнадну интерпретацију описаних догађаја и то скоро сто педесет година касније, узимајући у обзир и тзв. историјску последицу, која је, објективно гледано, била огромна, што се тиче тадашњег утицаја на арапско-исламску цивилизацију. Исто важи и за Гутасово навођење Исфаханија (893961) као поузданог извора за објашњавање устројства Куће мудрости (Gutas 1999: 54) и то због два разлога. Прво, ни Исфахани није био савременик оснивања и рада ове институције, а друго, још важније, он је познат као велики персијски националиста са јаким предрасудама против Арапа, због чега се његове речи морају узимати са резервом, јер није увек био непристрасан у својим анализама (Rosenthal 1986: III, 156). Ипак, то не умањује значај те Гутасове одличне студије која нуди изузетан увид у превођење са грчког на арапски. Што се пак тиче Итманове тврдње да је Кућа мудрости осмишљена по александријском моделу, тај египатски стручњак 
није успео да је поткрепи доказима нити било каквим озбиљним аргументима. И овде морамо напоменути да ни то не умањује пак вредност Итманове студије.

Из овог критичког прегледа најважнијих приступа проучавању Куће мудрости врло је јасно да су поуздане информације о њој врло штуре, непоуздане и неретко непоткрепљене, те да се често темеље на некритичком тумачењу информација из извора или на њиховом пуком понављању. То је уједно последица чињенице да арапске преводилачке активности у средњем веку нису задобиле истраживачку пажњу какву завређују, упркос свом неоспорном културолошком и цивилизацијском значају који далеко превазилази границе арапско-исламског света. Стога нам преостаје нада да ће се у будућности појавити другачији, критичкији приступи овој теми.

\section{Литература и извори:}

Baker, M. (ed.) Routledge Encyclopedia of Translation Studies. London: Routledge, 2005.

Dietrich, A. „Ibn Diuldiul“. B. Lewis et. al. (ed.), The Encyclopaedia of Islam. Leiden: E. J. Brill, 1986, III, 755-756.

Fück, J. „Ibn Nadim“. B. Lewis et. al. (ed.), The Encyclopaedia of Islam. Leiden: E. J. Brill, 1986 III, 895-896.

Gilliot, C. „Libraries“. Meri, J. W. (ed). Medieval Islamic civilization: an encyclopedia. New York: Routledge, 2006, 450-454.

Gutas, D.. Greek Thought, Arabic Culture: the Graeco-Arabic translation movement in Baghdad and early 'Abbasid society (2nd-4th/8th-10th centuries). London: Routledge, 1999.

Hiti, F. Istorija Arapa. Sarajevo: Veselin Masleša, 1988.

Хурани, А. Историја арапских народа. Београд: Клио, 2016.

Ibn 'Ușaybi'a. 'Uyūn al-'anbā' fi țabaqāt al-'ațibbā'. Manšūrāt Dār maktabat al-ḥayā: Bayrūt. s.a.

Ibn al-Nadīm. Fihrsit. Dār al-ma'rifa. Bayrūt. 1964.

'Itmān, 'A. al-Munğaz al-'arabī al-'islāmī fi al-tarğama wa ḥiwār al-țaqāfāt min Bag̉dād 'ilā Tulayțila. Al-Qāhira: al-Hay'a al-mișriyya al-'āmma li al-kitāb, 2013. Lamoreuax, J. C. (editor \& translator). Hunayn Ibn Ishāa on His Galen Translations. Provo: Brigham Young University Press, 2016 
Morrison, R. „Hunayn ibn Ishaq“. Meri, J. W. (ed). Medieval Islamic civilization: an encyclopedia. New York: Routledge, 2006, 336-337.

Osman, G. (2011). Translation and interpreting in the Arabic of the Middle Ages: lessons in contextualization. International Journal of the Sociology of Language, 207, 107-125.

Rosenthal, F. „Ḥamza al-'Ișfahānī“. B. Lewis et. al. (ed.), The Encyclopaedia of Islam. Leiden: E. J. Brill, 1986, III, 156.

Sourdel, D. „Bayt al-hikma“ B. Lewis et. al. (ed.), The Encyclopaedia of Islam. Leiden: E. J. Brill, 1986, I, 1141.

Ṭāha, S. (1976). Al-Ta'rīb wa kibār al-mu'arribīn fĩ al-'islām. Sūmir, 32, 339-389.

Vernet, J. „Ibn abī 'Ușaybi'a“. B. Lewis et. al. (ed.), The Encyclopaedia of Islam. Leiden:

E. J. Brill, 1986, III, 693-694.

\title{
Dragana Đorđević
}

\section{"HOUSE OF WISDOM" AND ARAB TRANSLATION ACTIVITIES IN THE MIDDLE AGES}

\begin{abstract}
Summary
"House of Wisdom", Ar. Bayt al-hikma, which is believed to be founded in Baghdad by the son of the famous Harun al-Rashid, khalif al-Ma'mūn in the 830, historiographic literature and sources usually mention as a translation center, a library, and an academy, as an axis of the Arab translation "movement" in the Middle Ages. The relevant literature that deals with the period and the translation activities, shows disagreement regarding the true nature and role of this institution in the intensive and comprehensive Arab Medieval translation activities of philosophical, scientific, medical, literary, and other works written in Greek, Persian, Sanskrit, Aramaic, etc. Secondary historiographic literature mostly describes "House of Wisdom" as a grandiose translation institution with certain modern organizational elements, especially coordinated work of sixty-five translators for Greek, Syriac, Persian, Aramaic and Sanskrit. Contrary to that, some newer studies postulate that most of these claims cannot be supported by reliable evidence: not the claim that "House of Wisdom", was founded khalif al-Ma'mūn or his father, nor that it witnessed translations from any other language than Persian. According to these studies, "House of Wisdom" was most likely a library, a part of Abbasid administration with
\end{abstract}


the primary to institutionalize translation from Persian and thus keep the obtained results. This paper critically analyzes different views of this institution and its role in Arab Medieval translation activities, as well as the reasons for such conflicting interpretations.

Key words: House of wisdom, Bayt al-hikma, history of translation, Arab translation activities 